\title{
Az Európai Unió földközi-tengeri haditengerészeti missziója és annak logisztikai vonatkozásai
}

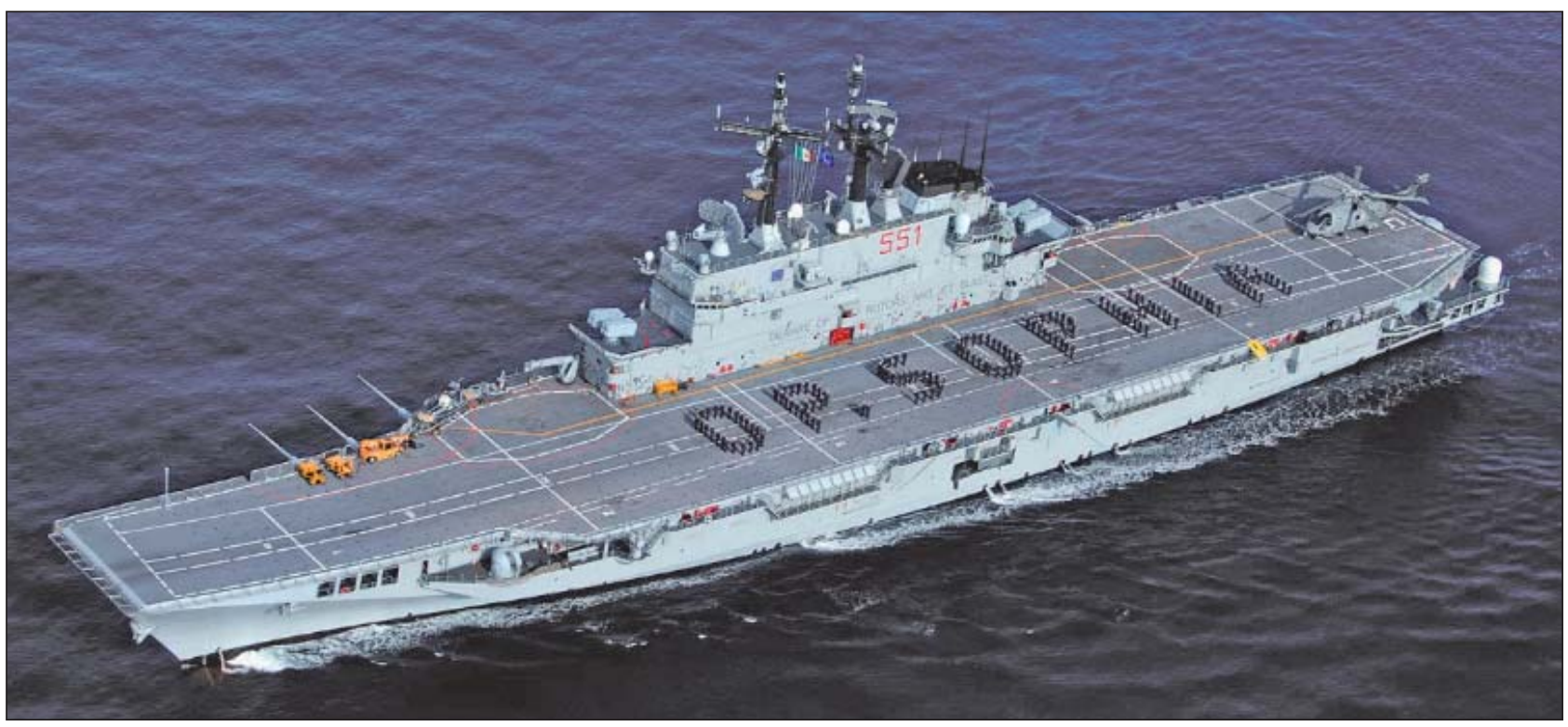

1. ábra. Az EU NAVFOR MED misszió zászlóshajója az ITS GARIBALDI helikopter-hordozó

\section{Bevezetés}

Az európai migrációs válság különböző fegyveres konfliktusok, a politikai és vallási üldöztetés, és az ezekből következő gazdasági ellehetetlenülés miatt menekülők vándorlása következtében alakult ki. Az egyre növekvő számú migráns főként a Közel-Keletről, Afrikából, a Balkánról és Közép-Ázsiából, a Földközi-tengeren és a Balkánon kialakult migránsútvonalakon keresztül igyekszik az Európai Unió területére jutni. A migránsok többsége Szíriából, Afganisztánból és Eritreából indul útnak. A „migrációs válság” kifejezést 2015 áprilisában használták először, amikor öt migránsokkal teli hajó süllyedt el, ezzel több, mint 1200 ember halálát okozva.

Az Európai Unió által 2015 májusában indított European Union Naval Force - Mediterranean (EUNAVFOR MED) missziót a fenti probléma lehetőség szerinti kezelésére hozták létre. A küldetésben a Magyar Honvédség törzstisz- tek delegálásával vesz részt. A balkáni útvonalon a Magyar Honvédség kulcsszerepet játszott és játszik az érkező migráns áradat megállításában. Ebből a célból részt vesz a déli határzár építésében, fenntartásában és őrzés-védelmében. Ugyanakkor a közép-mediterrán útvonal Olaszországra helyez óriási nyomást.

\section{A MISSZIó MEgaLaKítása}

2015. április 23-án az EU Külügyek Tanácsa és az Európai Tanács értekezletén merült fel egy nemzetközi művelet létrehozása. 2015. május 18-án megszületett a döntés egy katonai müvelet létrehozásáról és ezzel egyidejűleg aktiválásra került a római Műveleti Parancsnokság (Operational Headquarter; OHQ). Az EU műveletek vezetésére öt ilyen parancsnokság alakult, amelyet az 1. táblázat mutat be.
ÖSSZEFOGLALÁS: A migrációs válság lehetséges felszámolására, az illegális fegyvercsempészet megakadályozása és a Földközi-tengerbe süllyedő hajókon érkező emberek életének mentése hívta életre az EU NAVFOR MED katonai missziót. A líbiai kormányzat és a térség instabilitása megnehezíti a 2015 nyár elején indult Európai Unió égisze alatt múködő haditengerészeti misszió tevékenyégeit. Jelen tanulmányban a misszió bemutatása és logisztikai aspektusainak ismertetése a cél.

KULCSSZAVAK: EU NAVFOR MED, Földközi-tenger, Líbia, migráció, haditengerészet, logisztika
ABSTRACT: The military mission EU NAVFOR MED was launched with the aim of possible settling the migrant crisis, prevent illicit firearms trafficking and saving life of people who arrive by ships sinking into the Mediterranean Sea. Activities of the naval mission started in early summer of 2015 under the aegis of the European Union are made more difficult by the Libyan government and instability of the region. This study deals with this mission and its logistical aspects.

KEY WORDS: EU NAVFOR MED, the Mediterranean Sea, Libya, migration, navy, logistics 
Az aktiválás után egy héten belül 3 magyar törzstiszt kezdte meg a szolgálatot Rómában, akik közül egy fő a logisztikai főnökségen dolgozik, mint befogadó nemzeti támogatást tervező főtiszt.

1. táblázat. Az EU múveletek vezetésének öt parancsnoksága

\begin{tabular}{|l|l|l|}
\hline Egyesült Királyság & London & EUNAVFOR ATALANTA \\
\hline Franciaország & Párizs & nem aktív \\
\hline Olaszország & Róma & EUNAVFOR MED \\
\hline Németország & Potsdam & nem aktív \\
\hline Görögország & Larissza & nem aktív \\
\hline
\end{tabular}

\section{Az EUNAVFOR MED MISSZIÓ FELADATAI ÉS CÉLJAI}

- Módszeres erőfeszítéseket tesz, hogy azonosítsa, lefoglalja és megsemmisítse az emberkereskedők és embercsempészek által felhasznált hajókat és eszközöket annak érdekében, hogy hozzájáruljon egy szélesebb uniós erőfeszítéshez, amelyben a vonatkozó nemzetközi joggal összhangban, az embercsempész és emberkereskedő hálózatokat felszámolják a mediterrán térségben.

- Az embercsempész és emberkereskedő üzleti háló felszámolását követően a határt illegálisan átlépők száma olyan alacsony szintre csökken, amely már kezelhető az EUNAVFOR MED jelenléte nélkül.

A misszió 2015. június 22-én került megindításra 14 tagállam és 1000 fő részvételével, 12 hónapos mandátummal és 11,82 millió euró költségvetéssel. Az első fázisban, amelyhez 2015. július 7-re a misszió elérte a Kezdeti Müveleti Képességet (Initial Operational Capability, IOC), majd 35 nappal később a Teljes Műveleti Képességet (Full Operational Capability, FOC). A művelet időrendi felépítését 4 fázisban határozták meg, amelyet a 2. táblázat ismertet.

A 2. fázis további két részre van osztva: Alpha és Bravo. A 2/A fázisba a misszió 2015. október 7-én lépett be és azóta is ebben a fázisban van. Alpha fázis a nemzetközi vizeken hajtja végre a feladatot, a Bravo fázis a nemzetközi és a Líbia-parti vizeken. A nemzeti vizek határa a partoktól számítva 12 tengeri mérföld.

Embercsempész és emberkereskedő tevékenység gyanúja esetén szükség van a hajó feltartóztatására és a fedélzeten tartózkodó személyek átvizsgálására, a hajó útirányának megváltoztatására és a feltartóztatott személyek meghatározott kikötőbe való kivezetésére, illetve az em-

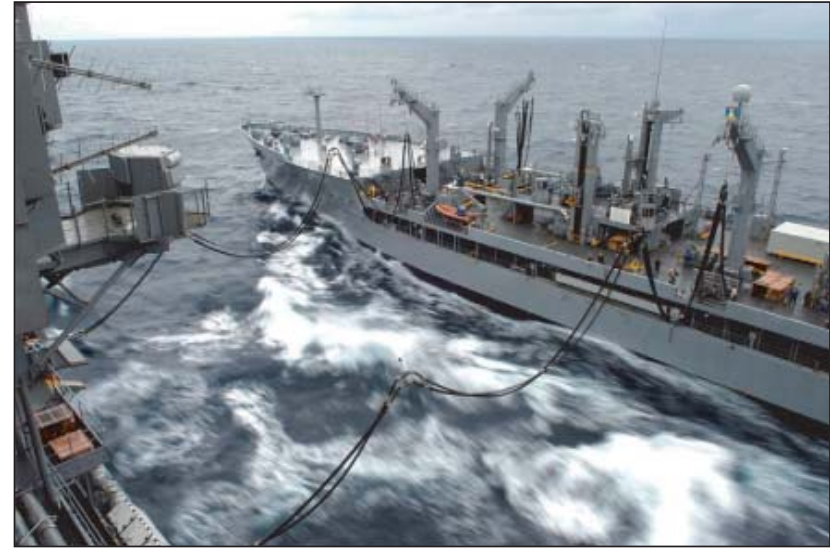

2. ábra. Tengeri utántöltés egy olajszállító hajóról az EU NAVFOR MED misszió során

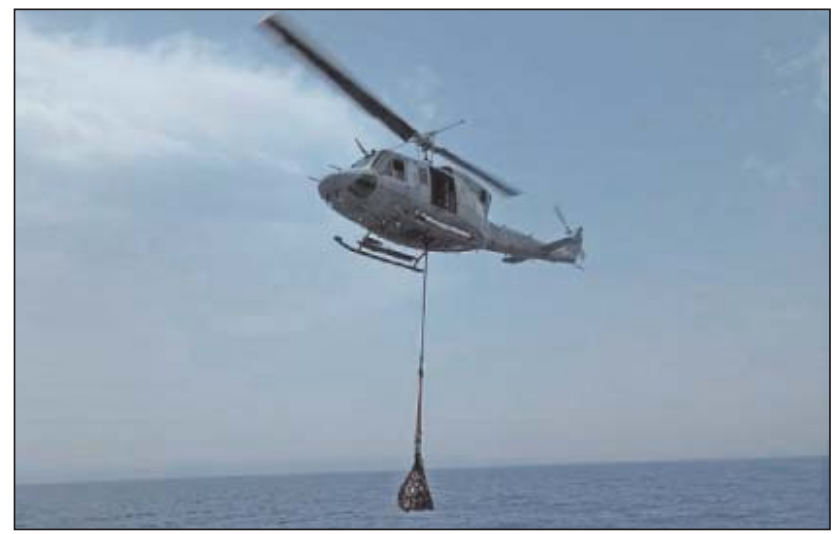

3. ábra. Augusta-Bell könnyühelikopter külső teheremeléssel szállít ellátmányt az EU NAVFOR MED misszióban

bercsempészek és emberkereskedők szabad mozgásának korlátozására, visszatartására, őrizetbe vételére, hogy megszakítsák ezt a büntetendő üzleti tevékenységet.

\section{A misszió úJ Megnevezése: Az EUNAVFOR MED Operation SOPHIA}

A névváltozás oka Sophia, aki 2015. augusztus 24-én hajnali 04:15-kor született a Földközi-tengeren, a német SCHLESWIG-HOLSTEIN fregatt fedélzetén. A szomáliai édesanyját 453 társával együtt mentették ki a tengerből. A babát a porosz származású Sophia Schleswig-Holstein (1866. április 8. - 1952. április 28.) hercegnőről nevezték el.

\section{2. táblázat. A misszió fázisai}

\begin{tabular}{|l|l|l|}
\hline 1. FÁZIS & Kitelepülés és felmérés & $\begin{array}{l}\text { Az embercsempész és emberkereskedő hálózat üzleti modelljének } \\
\text { feltérképezése, megfigyelése és megértése. }\end{array}$ \\
\hline 2. FÁZIS & Megerősítés és biztosítás & $\begin{array}{l}\text { Hajók megállítása, átszállás és keresés az ellenőrzött hajón. A rakományról és } \\
\text { a fedélzeten tartózkodó személyekról információk, bizonyítékok gyűjtése, } \\
\text { átvizsgálás. }\end{array}$ \\
\hline 3. FÁZIS & Semlegesítés/felszámolás & $\begin{array}{l}\text { Az embercsempész és emberkereskedő hajók és más eszközök } \\
\text { semlegesítése/megsemmisítése korlátozott és átmeneti módon végrehajtott } \\
\text { speciális és „kétéltű” műveletekkel. A 3. fázis végén az embercsempész és } \\
\text { emberkereskedő tevékenység jelentős csökkentése olyan szintre, hogy azt } \\
\text { már az érintett országok önállóan kezelni tudják. }\end{array}$ \\
\hline 4. FÁZIS & Visszatelepülés & A katonai erők visszatelepítése a résztvevő nemzetek hazai bázisaira. \\
\hline
\end{tabular}


Az Európai Unió külügyi és biztonságpolitikai főképviselője, Federica Mogherini 2015 szeptemberében kezdeményezte a misszió nevének megváltoztatását.

A művelet működési területe észak-déli irányban 600 km, amely 20-24 óra alatt áthajózható. Kelet-nyugati irányban 1200 km, amely 40-48 óra alatt teljesíthető, ez a terület felöleli Líbia partszakaszát és a Földközi-tenger ezen részének déli területeit.

Az EUNAVFOR MED Operation Sophia mellett a térségben tevékenykedik az olasz parti őrség, a FRONTEX műveletei (a Poseidon és a Triton), a NATO Operation Sea Guardian és számos nem kormányzati szervezet (NonGovermental Organization, NGO), mint például a Save the children (Védd a gyermekeket) vagy a Médecins sans Frontières (Orvosok határok nélkül) szervezete.

\section{A MISSZIó FELÉPITÉSE}

A missziót az $\mathrm{OHQ}$ vezeti, amelynek a végrehajtó erők irányításra létrehoztak egy hadműveleti parancsnokságot (Force Headquarter, FHQ). Az OHQ stratégiai, az FHQ hadműveleti és harcászati szinten hajtja, vagyis hajtaná végre a feladatait. Érdekes adat, hogy az OHQ logisztikai főnökség létszáma 11 fő, míg az FHQ ezen részlege csak 3 fő, amelyből egy beosztás nem volt felöltve, így a vezetési szintek sok esetben eltolódtak. (A létszámadatok hasonlóak a többi főnökség, részleg relációjában is.)

Az OHQ felettes szerve az Európai Unió Katonai Törzs (European Union Military Staff EUMS), de alatta müködik és felettes parancsnoksága az FHQ-nak. Az FHQ alárendeltségében működnek az alegységek, azaz a hajók, a légi felderítést végző repülők és az Olaszország által felajánlott és kijelölt bázisok (3. táblázat).

A kezdetekhez képest 2016 novemberében 25 tagország és ennek 2261 főnyi személyzete vett rész a műveletben. Ezen számadatok a végrehajtó erők felajánlása függvényében folyamatosan változtak. A múveletet parancsnoka a megalakítása óta Enrico Credendino olasz ellentengernagy. A törzsállomány általában félévente kerül leváltásra, de ettől a nemzetek sok esetben 2-12 hónapos tartományban eltérnek.

Egy évvel a megalakítás után, az Európai Unió Tanácsa 2016. május 23-án az EUNAVFOR MED Operation Sophia műveletről szóló következtetéseiben egyrészt üdvözölte, hogy a líbiai nemzeti egységkormány elnöki tanácsának

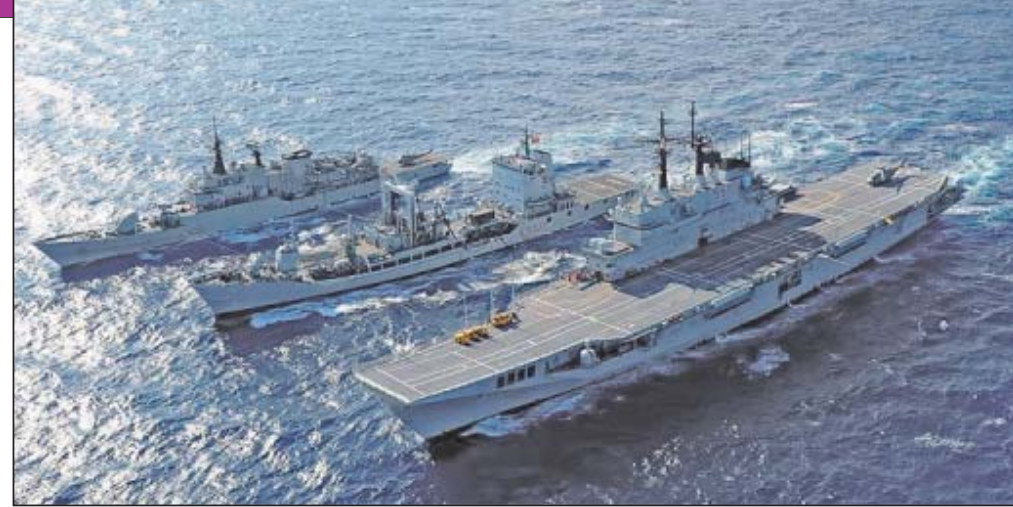

4. ábra. Az ITS GARIBALDI helikopter-hordozó tengeri utántöltése egy olajszállító hajóról

elnöke kinyilvánította, hogy az Unióval e következtetések alapján kész együttműködni, másrészt egyetértett abban, hogy az EUNAVFOR MED Operation Sophia művelet megbízatását egy évvel meg kell hosszabbítani, és annak alapvető feladatát továbbra is fenntartva, a múveletet további két támogató feladattal kell megbízni (4. táblázat).

Az ENSZ Biztonsági Tanács 2016. június 14-én elfogadta a Líbiával szemben bevezetett fegyverembargóról szóló 2292 (2016) sz. ENSZ BT (Biztonsági Tanácsa) határozatot, amelyben különösen kifejezte aggodalmát, hogy az illegális fegyverek és a kapcsolódó felszerelések csempészete tovább súlyosbítja a líbiai helyzetet.

\section{A LOGISZTIKAI TÁMOGATÁSI KONCEPCIÓ}

Az OHQ és a FHQ szervezeti felépítése a NATO terminológiához hasonlóan épül fel. A logisztikai főnökség a 4-es főnökség (OHQ Combined Jonit-4 [CJ-4] és FHQ CJ-4). Az $\mathrm{OHQ}$ CJ-4 szervezete a klasszikus logisztikai felépítés, ahol megjelenik a logisztikai hadművelet, a tervezés, a befogadó nemzeti támogatás és a közlekedés.

A művelet részére felajánlott eszközök fenntartása, üzemeltetése - az összes költséggel együtt - a küldő nemzet felelősségi körében maradt. Logisztikai támogatási technikai egyezmény került megkötésre az EUNAVFOR MED Operation Sophia és Olaszország között, amelyhez csatlakoztak a nemzetek, amely révén igénybe tudják venni az Olaszország által felajánlott befogadó nemzeti támogatásokat.

A repülő eszközök esetében a sigonellai bázis az, ahol a légi eszközök feltöltését és állomásoztatást hajtják végre. Prioritást élvez az üzemanyag vételezési lehetősége, a tá-

3. táblázat. FHQ alárendeltségében müködő alegységek

\begin{tabular}{|l|l|}
\hline $\begin{array}{l}\text { Elöretolt Műveleti Bázis } \\
\text { (Forward Operating Base, FOB) } \\
\text { Sigonella }\end{array}$ & Olasz légi támaszpont, ahol a misszió repülőgépei is állomásoznak. \\
\hline $\begin{array}{l}\text { Előretolt Logisztikai Bázis (Forward } \\
\text { Logistics Base, FLB) Augusta }\end{array}$ & $\begin{array}{l}\text { Az elöretolt logisztikai bázis egyben tengeri kikötő is, ahol a hajók } \\
\text { utántöltését, kisjavítását, karbantartását végezik. }\end{array}$ \\
\hline $\begin{array}{l}\text { Elöretolt Logisztikai Helyszín } \\
\text { (Forward Logistics Site, FLS) } \\
\text { Pantelleria }\end{array}$ & $\begin{array}{l}\text { Egy olasz szigeten települt légi kikötő, ahol a repülőeszközök végre tudták } \\
\text { hajtani a szükséges légi feltöltéseket és az esetleges földi kiszolgálásokat. }\end{array}$ \\
\hline
\end{tabular}

4. táblázat. A misszió új feladatai

\begin{tabular}{|l|l|}
\hline Kapacitásépítés és képzés & $\begin{array}{l}\text { A líbiai parti őrség és haditengerészet részére kell biztosítani, valamint a } \\
\text { velük való információ-megosztás a legitim líbiai hatóságok kérése alapján, } \\
\text { figyelembe véve a líbiai szerepvállalás fontosságát. }\end{array}$ \\
\hline $\begin{array}{l}\text { ENSZ fegyverembargójának } \\
\text { végrehajtása }\end{array}$ & $\begin{array}{l}\text { A líbiai partokhoz közeli nyílt tengeren, egy új ENSZ BT-határozat alapján, } \\
\text { valamint az információ-megosztás elősegítése. }\end{array}$ \\
\hline
\end{tabular}




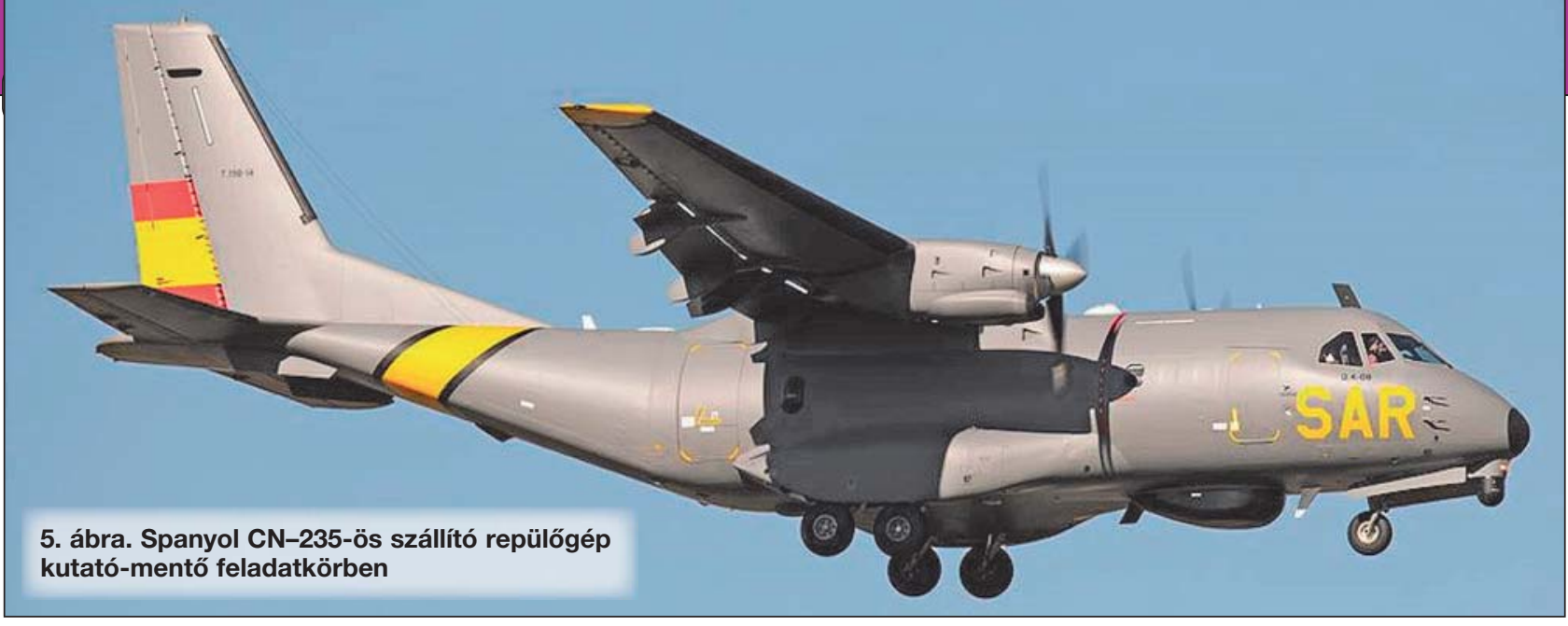

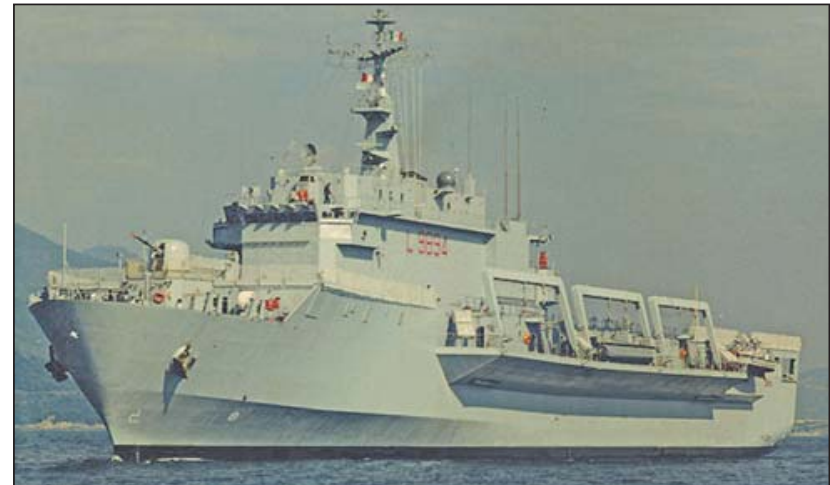

6. ábra. Az olasz SAN GIORGO partra szállító hajó (LPD - Landing Platform Dock)

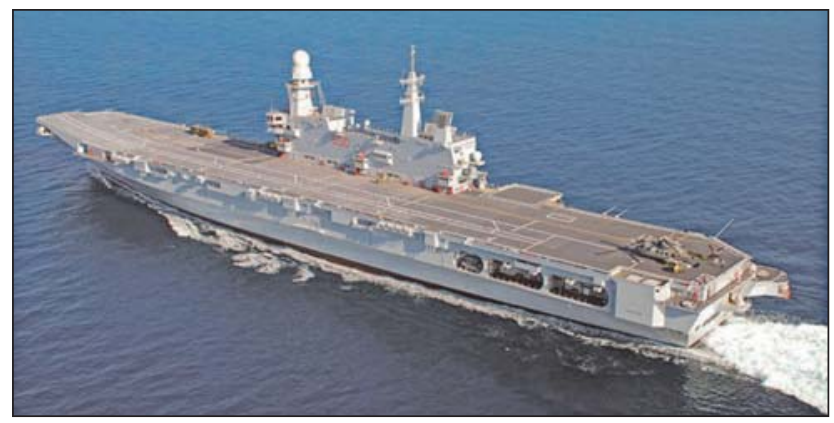

7. ábra. Az olasz CAVOUR repülögép-hordozó

rolási kapacitás, az élelmezési és a javító munkaállomás biztosítása.

A hadihajók esetében az augustai az előretolt logisztikai bázis, ahol a hajók logisztikai kiszolgálását hajtják végre. Fő tevékenység az üzemanyag, a tárolási kapacitás - külön lőszer is -, az élelmezési, elhelyezési és postai szolgáltatás biztosítása. Természetesen a hajók más kikötők (Málta, Olaszország további kikötői, Görögország) szolgáltatásait is igénybe vették kétoldalú egyezmények alapján.

A hadihajók folyamatos cirkálásának fő feltétele az üzemanyag-utánpótlás. A misszió részére eddig még egyetlen nemzet sem ajánlott fel tengeri utántöltésre képes üzemanyagszállító hajót, annak ellenére, hogy ez szerepelt a misszió igénylistájában. Az OHQ CJ-4 szervezésében - a kikötői látogatások, feltöltések számának csökkentése érdekében - a NATO és az USA erőkkel történt egyeztetés után a térségben települt NATO üzemanyag-szállító több esetben is feltöltötte az EUNAVFOR MED Operation Sophia hajóit.

A szerző eredeti beosztása mellett logisztikai tervező tisztként került delegálásra a misszió kiemelt tervező csoportjába (Senior Officer Team [SOT]). Ezen csoport foglalkozott a líbiai haditengerészeti és parti őrség kiképzésének előkészítésével, amely során többször tárgyaltak a líbiai féllel. Főbb feladatai közé tartozott az igényelt kiképzési anyagok biztosítása, az állomány a felkészítés helyére juttatása - egy speciális kiválasztási eljárás után -, a kiképzendő és kiképző állomány ellátása (speciális "HALAL” kategóriájú étel biztosítása) ${ }^{1}$, valamint az egyetértési megállapodás logisztikai részének kidolgozása, ezek megszervezése és biztosítása.

\section{A MISSZIÓ VÉGREHAJTÓ ERÖI}

A korábban bemutatott szárazföldi bázisok mellett természetesen a főszerepet a hajók és a repülőgépek jelentették. Az európai nemzetek különböző rotációval ajánlották fel a hajóikat, eszközeiket. Az eszközök csatlakozása és kivonása szinte heti szinten változott. A misszió zászlóshajója, ahol az FHQ is települ 2016 nyarán a ITS GARIBALDI volt,

\section{8. ábra. Migránsokat szállító hajó elsüllyedése és az emberek} kimentése a vízböl
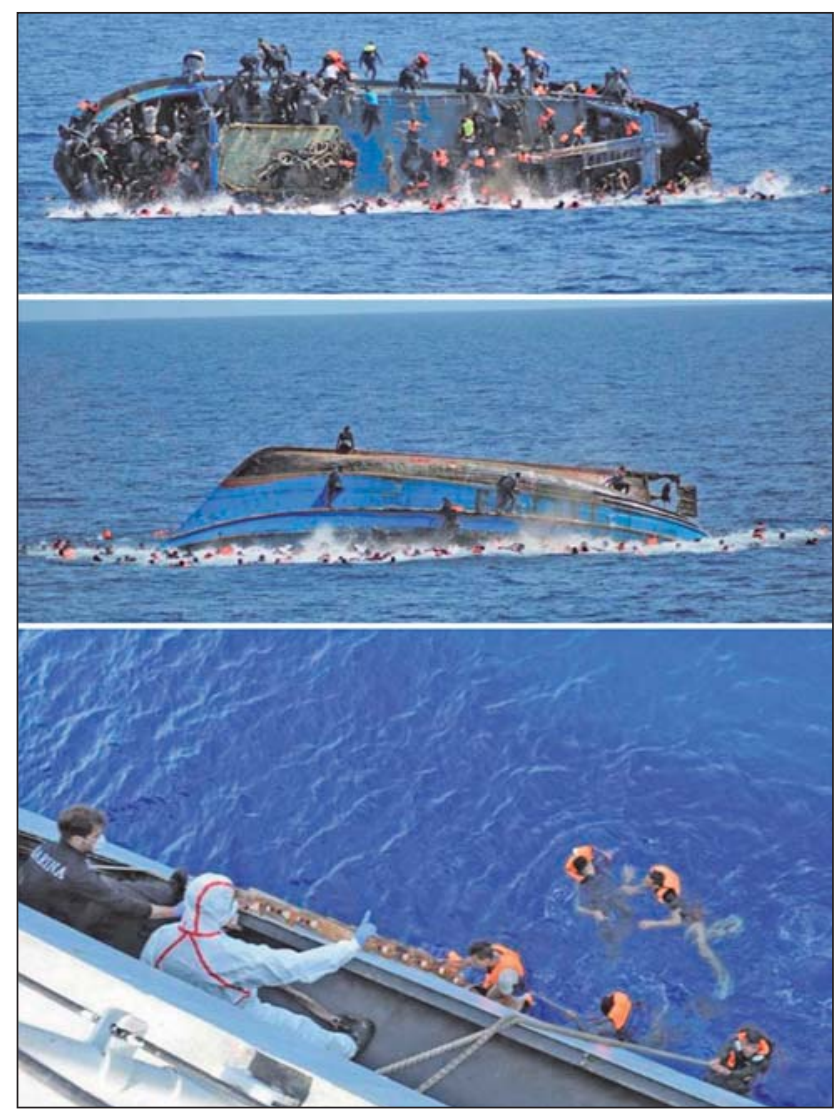


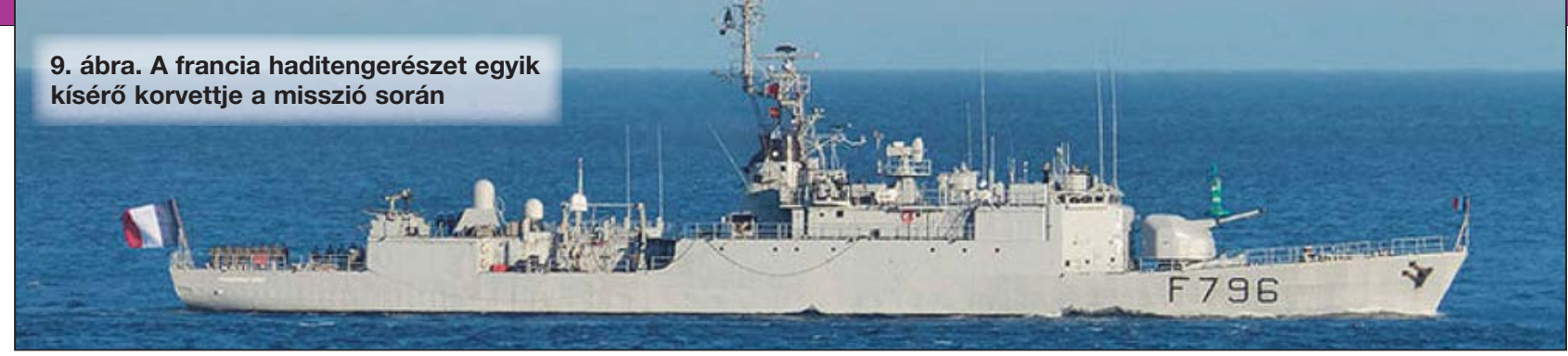

de előtte a ITS CAVOUR töltötte be ezt a szerepet. 2016 novemberében 8 darab hajó, 4 darab repülőgép és 5 darab helikopter végezte a feladatokat. (Olasz, német, angol, francia, belga és holland nemzeti hozzájárulásból.)

\section{A MAGYAR TÖRZSTISZTEK}

A feladatott 3 fő kezdte el az első váltásban, 2 fő a hadműveleti és egy fő a logisztikai főnökségen dolgozott. A második félévben csak 2 fő folytatta a beosztások ellátását, egy fő hadműveleti és egy fő a logisztikai főnökségen. A harmadik félévben újabb beosztás került felvállalásra a felderítő főnökségen.

\section{A MISSZIÓ EREDMÉNYEI SZÁMOKBAN}

A misszió első 1,5 évben² 205 alkalommal mentett ki 29879 embert $^{3}$, ebből:

23318 férfi (78\%),

4798 nő (16\%),

1740 gyerek (6\%), illetve további 23 csecsemő.

Elfogott 101 embercsempészt, emellett 348 db hajót süllyesztett el. Sajnálatos módon a hajó értéke igen csekély az embercsempészek hasznához képest, így feláldozása nem okoz gondot a számukra.

A statisztikákból kiderül, hogy félévente megduplázódott a hajók száma és 50\%-kal több migráns érkezett az előző félévekhez képest. Egyetlen számadat mutat csökkenést, az elfogott embercsempészek száma. Ennek oka, hogy kivontatják a hajókat a nemzeti és nemzetközi vizek határára és onnan jobb esetben leadják a segélyhívást, rosz- szabb esetben magára hagyják a hajót, ami sok esetben egy nagyobb méretű gumicsónak, motor nélkül.

A missziónak nem alapfeladata a SOLAS (Safety of Life at Sea), azaz emberi élet mentése a tengerből, de alapvető emberi kötelesség és az 1974-es nemzetközi tengeri jog alapján, illetve a művelet létrehozásának egyik indoka, hogy ne vesszen több élet a Földközi-tengerbe.

A 2016. április 4-ei ${ }^{4}$ időpont óta jól látható, hogy a migrációs nyomás áthelyeződött a középső, azaz a tengeri útvonalra. A problémáját jelzi, hogy a témában, az utóbbi időben több Európai Unió szintű felsővezetői konferencia volt, de végleges megoldása azóta sincs.

\section{ÖSSZEFOGLALÁs}

Az egész migrációs válság óriási feladatokat ró a nemzetekre, az európai állampolgárokra és természetesen az EU NAVFOR MED Operation Sophia misszió részére is. A végleges megoldás jelenleg még csak körvonalazódik, amelyben kulcsszerepet játszik Líbia. Remélhetőleg rövidesen sikerül a résztvevő országoknak megegyezni és nem következik be ennyi emberi élet elvesztése.

\section{JEGYZETEK}

1 A „halal” fogalma az Iszlám jog szerint azt jelenti: megengedett, törvényes. Élelmiszerekre vonatkoztatva olyan élelmiszert jelent, amelyek fogyasztása a muszlimok számára megengedett. 2 2015. június -2016 . november

3 2015-ben 153000 , 2016-ban 181000 fö kelt át a tengeren.

4 EU-Törökország közötti megállapodás életbe lépése.

\section{Karrier lehetőség a
Magyar Honvédség Logisztikail Központban:}

Felsőfokú műszaki végzettségúek jelentkezését várjuk haditechnikai fejlesztések és beszerzések müszaki támogatása területén, valamint minőségirányítási rendszertanúsítás és múszaki átvételi területeken történó munkavégzésre.

\section{Amit ajánlani tudunk:}

Kiszámítható és tervezhető munkalehetőség,

Stabil munkahely,

Gyakorlati tapasztalat szerzés,

- Továbbképzési lehetőség,

- Közalkalmazottak jogállásáról (1992. évi XXXIII.) szóló törvény szerinti illetmény, ágazati pótlék, keresetkiegészítés + béren kívüli juttatások (utazási hozzááárulás, éves ruházati költségtérítes, OTP Széchenyi Kártya, étkezési hozzájárulás, kedvezményes üdültetés).

\section{J elentkezés:}

nqaa@hm.gov. hu e-mail címen,

- Szakmai önéletrajz, valamint motivációs levél csatolásával.

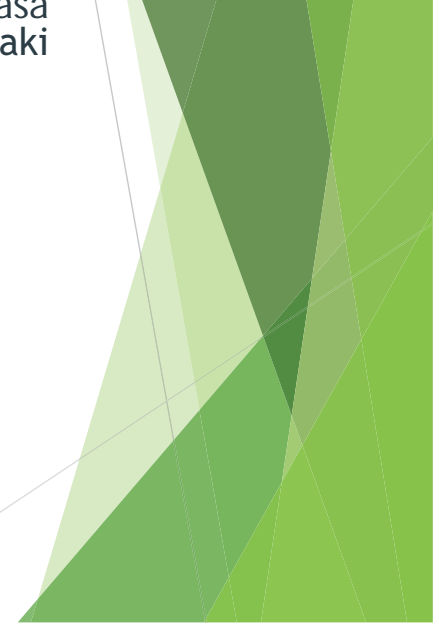

